\title{
Chemistry and quality of groundwater in a coastal region of Andhra Pradesh, India
}

\author{
N. Subba Rao $\cdot$ G. Vidyasagar $\cdot$ P. Surya Rao $\cdot$ \\ P. Bhanumurthy
}

Received: 11 February 2014/ Accepted: 16 October 2014/Published online: 8 November 2014

(C) The Author(s) 2014. This article is published with open access at Springerlink.com

\begin{abstract}
The chemistry of groundwater in the coastal region between Chirala and Ongole of Andhra Pradesh, India shows pollution to varying extent. The relative contribution of ions in six zones divided based on TDS indicates unsuitability of groundwater here for drinking, irrigation and industrial use. The water is brackish except in first zone and further alkaline. TDS is less than $1,000 \mathrm{mg} / \mathrm{L}$ in first zone, while it is more in other zones. This classification of groundwater into zones is also investigated by hydrogeochemical facies, genetic classification, mechanisms of groundwater chemistry and geochemical signatures. Hydrogeochemical facies of $\mathrm{Na}^{+}>$ $\mathrm{Mg}^{2+}>\mathrm{Ca}^{2+}: \mathrm{HCO}_{3}^{-}>\mathrm{Cl}^{-}>\mathrm{SO}_{4}^{2-}$ is observed from zone I, while that of $\mathrm{Na}^{+}>\mathrm{Mg}^{2+}>\mathrm{Ca}^{2+}: \mathrm{Cl}^{-}>\mathrm{HCO}_{3}^{-}>\mathrm{SO}_{4}^{2-}$ from second to sixth zones. The genetic classification of groundwater in first and second zones is $\mathrm{HCO}_{3}^{-}$type and supported by good drainage conditions, while zones III to VI belong to $\mathrm{Cl}^{-}$category evident from poor drainage scenario. The location of six zones on mechanisms of groundwater chemistry supports sluggish drainage conditions of second to six zones, while predominate rock-water interaction in first zone. The geochemical signatures $\left(\mathrm{HCO}_{3}^{-}: \mathrm{Cl}^{-}>1\right.$ and $\left.\mathrm{Na}^{+}: \mathrm{Cl}^{-}<1\right)$ also endorse the pollution. The quantities of chemical species $\left(\mathrm{Mg}^{2+}, \mathrm{Na}^{+}, \mathrm{K}^{+}\right.$, $\mathrm{HCO}_{3}^{-}, \mathrm{Cl}^{-}, \mathrm{SO}_{4}^{2-}, \mathrm{NO}_{3}^{-}$and $\mathrm{F}^{-}$) and TDS in all zones are far greater than the stipulated limits for drinking. The United States Salinity Laboratory plots discriminated the suitability of groundwater in second to sixth zones for irrigation after only special soil treatment. Higher
\end{abstract}

N. S. Rao $(\bowtie) \cdot$ G. Vidyasagar · P. Surya Rao ·

P. Bhanumurthy

Department of Geology, Andhra University,

Visakhapatnam 530 003, India

e-mail: srnandipati@gmail.com concentrations of TDS, $\mathrm{HCO}_{3}^{-}, \mathrm{Cl}^{-}$and $\mathrm{SO}_{4}^{2-}$ in all zones render it unsuitable for industry too. This information is crucial for public and civic authorities for taking up strategic management plan for preventing further deterioration of hydrogeochemical environmental conditions of this part of the coastal region.

Keywords Groundwater chemistry · Quality · Coastal Region · Andhra Pradesh · India

\section{Introduction}

India has a very long coastline of nearly $7,500 \mathrm{~km}$, including its island territories. More than $30 \%$ of the population in the country lives along the coastal region. The coastal regions contribute significantly to socio-economic growth of the country. The intensive agricultural activities and exponential industrial growth along the coastal region are a result of liberalized governmental policies and financial support. The anthropogenic wastes deteriorate quality of water resources, including groundwater. Toxic minerals like apatite and arsenite of the country rocks and transgression and incursion of seawater further decline quality of groundwater.

Subba Rao et al. (2005) assessed polluting effects of seawater and urban waste waters on groundwater in the coastal area of Visakhapatnam, Andhra Pradesh. Senthilkumar et al. (2008) studied hydrogeochemistry of groundwater in the Cuddalore coastal region of Tamilnadu. Chidambaram et al. (2009) probed into influencing factors in leaching of salts on groundwater quality in a selected part of Cuddalore district. Manjusree et al. (2009) assessed quality of groundwater for potability and agricultural uses in the coastal aquifer in Chennam-Pallippuram Panchayath, 
Alappuzha district, Kerala. Bhavana et al. (2011) reported groundwater quality in the Guhagar coastal area, Maharashtra. Bhishm Kumar et al. (2011) studied groundwater management in a coastal aquifer in Krishna River Delta, South India, using isotopic approach. Mondal et al. (2011) described hydrochemical characteristics of the coastal aquifer from Tuticorin, Tamil Nadu. Srinivasamoorthy et al. (2011) found rock-weathering, ion-exchange and anthropogenic processes as dominant factors on groundwater quality in an eastern coastal area of Cuddalore district. Sarath Prasanth et al. (2012) evaluated groundwater quality and its suitability for drinking and agricultural use in the coastal stretch of Alappuzha District. Reddy (2013) and Selvam et al. (2013) reported hydrogeochemical characteristics in groundwater of the southeastern coastal belt of Prakasam district, Andhra Pradesh and in the coastal aquifer of Tuticorin, respectively. Sajil Kumar et al. (2014) and Venkataramanan et al. (2014) assessed hydrochemistry and groundwater quality in the coastal regions of Muthupet and South Chennai, Tamilandu, respectively. Surya Rao and Subba Rao (2014) probed into quality of groundwater in a coastal region of Srikakulam district, Andhra Pradesh.

During the field survey conducted in the coastal region of Andhra Pradesh, India (Fig. 1), salt-making industry, aqua-cultural activities and occurrence of clay on surface as well as in sub-surface at different depths have been observed. Occupational health hazards viz. skin cracks, eye problems, hypertension and abortions are reported in the workers of salt-making activities on constant and prolonged exposure. Further, a decrease in crop yields and increase of susceptibility for plant diseases are reported in this area. The opinion gathering showed marked arthritis and fluorosis among all ages of people. We report now the

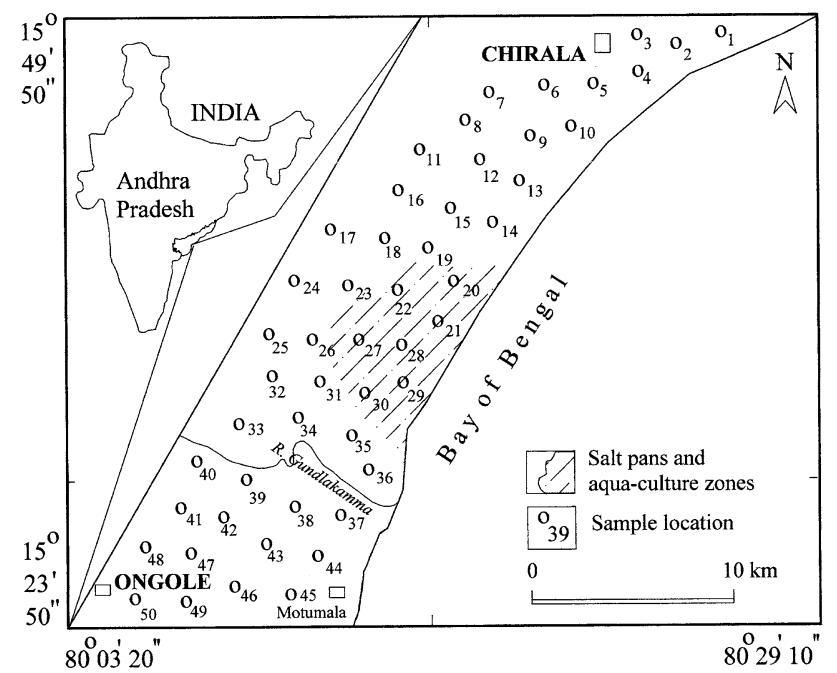

Fig. 1 Location of the study area results of our study, focusing on (a) delineation of polluted groundwater zones based on total dissolved solids, (b) evaluation of relative contribution of ions to each pollution zone and (c) impact of contaminated groundwater on human health, crop yield and industrial growth in each zone. These results pave the way for environmental and policy-makers to stipulate appropriate management steps in remedial measures of pollution and eco-balance of the coastal regions.

\section{Study area}

\section{Location}

The present chosen area of coastal region between Chirala and Ongole (latitudes $80^{\circ} 29^{\prime} 10^{\prime \prime}-80^{\circ} 03^{\prime} 20^{\prime \prime}$ East and longitudes $15^{\circ} 23^{\prime} 50^{\prime \prime}-15^{\circ} 49^{\prime} 50^{\prime \prime}$ North) is about $40 \mathrm{~km}$ in length from north to south and $10-20 \mathrm{~km}$ in width from east to west (Fig. 1). It experiences a semi-arid climate, with an annual average temperature of $19.7^{\circ}$ in winter to $41.7{ }^{\circ} \mathrm{C}$ in summer. The annual rainfall is about $900 \mathrm{~mm}$. The area is drained by the river Gundalakamma, which shows a sub-dendritic pattern.

\section{Geology}

The study area slopes gently towards the coast. Silty clay, sand and black cotton soils are the dominant types in this region. Relatively, sand is more in northern part, while clay (silty clay and black cotton soils) increases towards southern part. Occurrence of kankar (concretion of $\mathrm{CaCO}_{3}$ ) in soil zone is a characteristic feature of dry climate. Charnockite rocks (contain $\mathrm{F}$-bearing minerals, apatite, hornblende and biotite) belonging to Archaeans are dominant in and around Ongole area (Fig. 1). River alluvium and coastal alluvium of recent age occur over the country rocks. The alluvium spreads along the river Gundalakamma and the coast.

The sub-surface geology reveals fine, fine to medium and medium sand at depths of less than 0.50, 0.50-16 and 16-22 m from ground surface, respectively, at Chirala (Central Ground Water Board 2002). And also, it shows fine sand with clay from a depth of less than $3 \mathrm{~m}$, followed by fine to medium sand with clay, quartzite pieces with clay and kankar, gravel with sand and clay, and clay with fine sand from depths of 3 to 10,10 to 34,34 to 64 and 64 to $174 \mathrm{~m}$ from surface, respectively, at Motumala.

\section{Hydrogeology}

Groundwater is extracted through open dug wells and bore wells for drinking and irrigation in the study area. It exists 
under water table conditions as well as under semi-confined to confined conditions due to occurrence of alternative sand and clay layers at different depths. Water level varies from 7.50 to $13.60 \mathrm{~m}$ below ground level and direction of water flow being towards southeastern side.

\section{Sources of pollution}

Salt pans and aqua-cultural activities are dominant in central part of the study area (Fig. 1). Irrigation practices are intensive and long-term. Usage of uncontrolled soil amendments and agricultural fertilizers is not uncommon for higher crop yields in the area. Drainage facilities, dumping of domestic wastes on open places and faulty construction of septic tanks are not an exception.

\section{Experimental}

Sampling and water analysis

Fifty groundwater samples collected from the study area during summer (May) 2011 (Fig. 1) were analyzed for chemical variables, $\mathrm{pH}$, total dissolved solids (TDS), calcium $\left(\mathrm{Ca}^{2+}\right)$, magnesium $\left(\mathrm{Mg}^{2+}\right)$, sodium $\left(\mathrm{Na}^{+}\right)$, potassium $\left(\mathrm{K}^{+}\right)$, bicarbonate $\left(\mathrm{HCO}_{3}^{-}\right)$, chloride $\left(\mathrm{Cl}^{-}\right)$, sulphate $\left(\mathrm{SO}_{4}^{2-}\right)$, nitrate $\left(\mathrm{NO}_{3}^{-}\right)$and fluoride $\left(\mathrm{F}^{-}\right)$, adhering to the standard water quality procedures (APHA 1999). $\mathrm{pH}$ and electrical conductivity (EC) were measured in the field, using portable $\mathrm{pH}$ and EC meters. Total dissolved solids were calculated from EC, according to the procedure of $\mathrm{Hem}$ (1991). Total alkalinity (as $\mathrm{CaCO}_{3}$ ) and $\mathrm{HCO}_{3}^{-}$were estimated by titrating with standard $\mathrm{HCl}$. Total hardness (as $\left.\mathrm{CaCO}_{3}\right)$ and $\mathrm{Ca}^{2+}$ were analyzed volumetrically, using standard EDTA. Magnesium was computed, taking difference between $\mathrm{TH}$ and $\mathrm{Ca}^{2+}$. A flame photometer was used for estimation of $\mathrm{Na}^{+}$and $\mathrm{K}^{+}$ions. Chloride was analyzed by titrating with standard $\mathrm{AgNO}_{3}$. Sulphate, $\mathrm{NO}_{3}^{-}$ and $\mathrm{F}^{-}$were determined, using turbidimetric, colorimetric and ion selective electrode methods, respectively. Units of EC are expressed in micro-siemens per centimeter $(\mu \mathrm{S} / \mathrm{cm})$ at $25{ }^{\circ} \mathrm{C}$, while those of the remaining chemical variables (except $\mathrm{pH})$ in milligrams per liter $(\mathrm{mg} / \mathrm{L})$.

\section{Ionic-balance}

Ionic-balance-error between total concentrations of cations $\left(\mathrm{Ca}^{2+}, \mathrm{Mg}^{2+}, \mathrm{Na}^{+}\right.$and $\left.\mathrm{K}^{+}\right)$and anions $\left(\mathrm{HCO}_{3}^{-}, \mathrm{Cl}^{-}, \mathrm{SO}_{4}^{2-}\right.$, $\mathrm{NO}_{3}^{-}$and $\mathrm{F}^{-}$) expressed in milliequivalent per liter (meq/L) are within the acceptable limits of $\pm 5 \%$ (Domenico and Schwartz (1990).
Methods for chemical and quality measures of groundwater

For overall scenario of chemistry and quality of groundwater, the standard procedures of hydrogeochemical facies (Seaber 1962; Back 1966), genetic classification (Chebotarev 1955) and mechanisms (Langelier and Ludwig 1942; Gibbs 1970) of groundwater chemistry, and geochemical signatures (Hem 1991) are used. The standard data base for assessing the water quality for drinking (Davis and Dewiest 1966; Holden 1970; BIS 2003), irrigation (Richards 1954) and industry (Johnson 1983) are used. The discussion follows on spatial discrimination into six polluted groundwater zones based on TDS.

\section{Results and discussion}

Values of $\mathrm{pH}$ (7.2-8.2) reveal an alkaline condition of groundwater (Table 1). Electrical conductivity varies from 1,310 to $5,200 \mu \mathrm{S} / \mathrm{cm}$. This indicates a wide range of salt enrichment in groundwater. Thus, TDS varies from 850 and $3,380 \mathrm{mg} / \mathrm{L}$. Twenty-two percent of groundwater samples comes under fresh (TDS $<1,000 \mathrm{mg} / \mathrm{L}$ ) and $78 \%$ under brackish (TDS: 1,000 to $10,000 \mathrm{mg} / \mathrm{L}$ ) categories (Fetter 1990). Concentrations (mg/L) of $\mathrm{Ca}^{2+}, \mathrm{Mg}^{2+}, \mathrm{Na}^{+}, \mathrm{K}^{+}$, $\mathrm{HCO}_{3}^{-}, \mathrm{Cl}^{-}, \mathrm{SO}_{4}^{2-}, \mathrm{NO}_{3}^{-}$and $\mathrm{F}^{-}$vary from 30 to 75,40 to 180,165 to 746,8 to 110,310 to 550,180 to $1,325,12$ to 232,39 to 123 and 0.60 to 1.80 , respectively. Standard deviation observed from the chemical variables varies over a wide range (0.33-716.67), indicating a large dispersion of salts in groundwater above their arithmetic mean values due to a large number of overlapping chemical processes.

\section{Groundwater pollution zones}

Spatial distribution of TDS (Fig. 2) is used to classify the present study area into six zones to grade the extent of groundwater pollution. A perusal of Table 2 shows that zone I contains fresh (uncontaminated) water (TDS $<1,000 \mathrm{mg} / \mathrm{L}$ ) and zones II to VI brackish nature (TDS $>1,000 \mathrm{mg} / \mathrm{L}$ ). There is a progressive increase from very low (TDS: $1,000-1,500 \mathrm{mg} / \mathrm{L}$ ) to very high brackish (TDS $>3,000 \mathrm{mg} / \mathrm{L}$ ) groundwater from zone II to zone VI. The iso-contour diagram (with latitudes and longitudes) indicates a progressive increase of TDS from northern, southern and western regions towards eastern (sea) side through central part. It is also observed the concentrations of $\mathrm{Na}^{+}$and $\mathrm{Cl}^{-}$ions follow a similar trend.

The concentration $\left(\mathrm{mg} / \mathrm{L}\right.$ ) of $\mathrm{HCO}_{3}^{-}$(417) in zone I (fresh groundwater) is more than the concentrations of $\mathrm{Cl}^{-}$(209), $\mathrm{Na}^{+}$(199), $\mathrm{SO}_{4}^{2-}$ (51), $\mathrm{Mg}^{2+}$ (48), $\mathrm{NO}_{3}^{-}$(43), $\mathrm{Ca}^{2+}(40), \mathrm{K}^{+}$ 
Table 1 Chemical composition of groundwater

\begin{tabular}{lllllll}
\hline Factors* & Unit & Minimum & Maximum & Mean & Standard deviation & Coefficient of variation \\
\hline $\mathrm{pH}$ & & 7.2 & 8.2 & 7.81 & 0.34 & 4.35 \\
$\mathrm{EC}$ & $\mu \mathrm{S} / \mathrm{cm}$ & 1,310 & 5,200 & $2,686.15$ & 715.56 & 41.12 \\
$\mathrm{TDS}$ & $\mathrm{mg} / \mathrm{L}$ & 850 & 3,380 & $1,745.80$ & 716.67 & 41.05 \\
$\mathrm{Ca}^{2+}$ & $\mathrm{mg} / \mathrm{L}$ & 30 & 75 & 48.60 & 12.90 & 26.54 \\
$\mathrm{Mg}^{2+}$ & $\mathrm{mg} / \mathrm{L}$ & 40 & 180 & 80.90 & 39.52 & 48.85 \\
$\mathrm{Na}^{+}$ & $\mathrm{mg} / \mathrm{L}$ & 165 & 746 & 399.12 & 182.17 & 45.64 \\
$\mathrm{~K}^{+}$ & $\mathrm{mg} / \mathrm{L}$ & 8 & 110 & 29.34 & 22.37 & 76.24 \\
$\mathrm{HCO}_{3}^{-}$ & $\mathrm{mg} / \mathrm{L}$ & 310 & 550 & 429.00 & 64.17 & 14.96 \\
$\mathrm{Cl}^{-}$ & $\mathrm{mg} / \mathrm{L}$ & 180 & 1,325 & 623.30 & 346.30 & 55.56 \\
$\mathrm{SO}_{4}^{2-}$ & $\mathrm{mg} / \mathrm{L}$ & 12 & 232 & 88.40 & 56.30 & 63.69 \\
$\mathrm{NO}_{3}^{-}$ & $\mathrm{mg} / \mathrm{L}$ & 39 & 123 & 51.84 & 22.89 & 44.16 \\
$\mathrm{~F}^{-}$ & $\mathrm{mg} / \mathrm{L}$ & 0.60 & 1.80 & 0.98 & 0.33 & 33.67 \\
\hline
\end{tabular}

* Factors influencing quality of groundwater

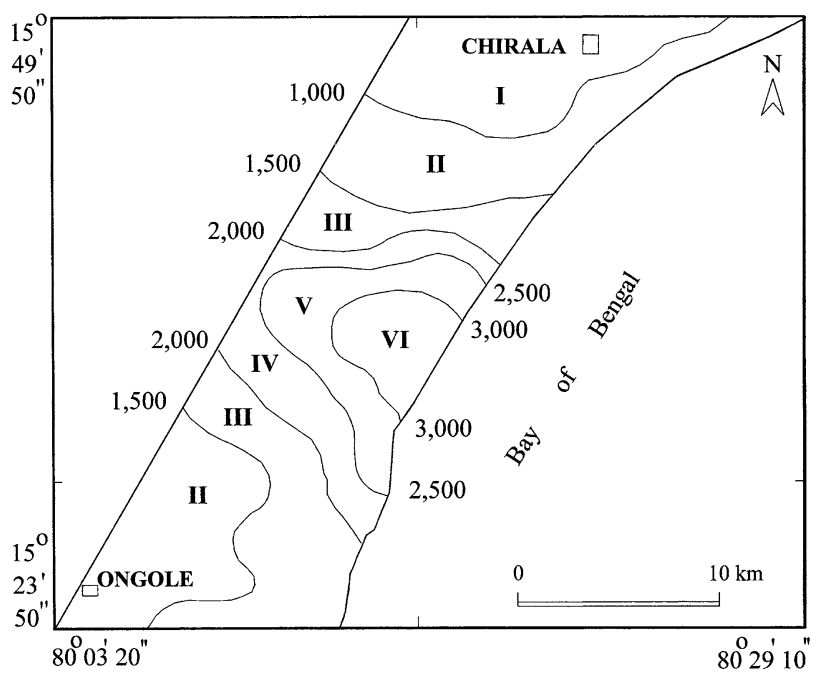

Fig. 2 Spatial distribution of TDS (mg/L)

(12) and $\mathrm{F}^{-}$(0.77; Table 3). Groundwater in zone II (very low brackish) shows a high concentration $(\mathrm{mg} / \mathrm{L})$ of $\mathrm{Cl}^{-}$(452) compared to that of $\mathrm{HCO}_{3}^{-}$(449), $\mathrm{Na}^{+}$(301), $\mathrm{Mg}^{2+}$ (67), $\mathrm{SO}_{4}^{2-}(62), \mathrm{Ca}^{2+}(47), \mathrm{NO}_{3}^{-}(42), \mathrm{K}^{+}$(22) and $\mathrm{F}^{-}$(0.87). A low brackish groundwater of zone III has a higher concentration $(\mathrm{mg} / \mathrm{L})$ of $\mathrm{Cl}^{-}$(662), following that of $\mathrm{HCO}_{3}^{-}$(419), $\mathrm{Na}^{+}$(415), $\mathrm{SO}_{4}^{2-}$ (71), $\mathrm{Mg}^{2+}$ (70), $\mathrm{Ca}^{2+}$ (51), $\mathrm{NO}_{3}^{-}$(42), $\mathrm{K}^{+}$ (24) and $\mathrm{F}^{-}$(0.90) ions. In zone IV, moderate brackish groundwater shows more concentration $(\mathrm{mg} / \mathrm{L})$ of $\mathrm{Cl}^{-}(775)$ than that of $\mathrm{Na}^{+}$(481), $\mathrm{HCO}_{3}^{-}$(423), $\mathrm{SO}_{4}^{2-}$ (103), $\mathrm{Mg}^{2+}$ (85), $\mathrm{NO}_{3}^{-}(59), \mathrm{Ca}^{2+}(50), \mathrm{K}^{+}(43)$ and $\mathrm{F}^{-}$(1) ions. Zone $\mathrm{V}$ (high brackish groundwater) has a higher concentration $(\mathrm{mg} / \mathrm{L})$ of $\mathrm{Cl}^{-}$(1,082), which is followed by $\mathrm{Na}^{+}$(678), $\mathrm{HCO}_{3}^{-}$(437), $\mathrm{SO}_{4}^{2-}$ (182), $\mathrm{Mg}^{2+}$ (115), $\mathrm{NO}_{3}^{-}$(80), $\mathrm{K}^{+}(57), \mathrm{Ca}^{2+}$ (47) and $\mathrm{F}^{-}$(1.27). In very high brackish groundwater of zone VI, a very higher concentration $(\mathrm{mg} / \mathrm{L})$ of $\mathrm{Cl}^{-}(1,288)$ is observed than that of $\mathrm{Na}^{+}$(692), $\mathrm{HCO}_{3}^{-}$(503), $\mathrm{Mg}^{2+}$ (185), $\mathrm{SO}_{4}^{2-}$ (156), $\mathrm{NO}_{3}^{-}$(84), $\mathrm{Ca}^{2+}$ (73), $\mathrm{K}^{+}$(58) and $\mathrm{F}^{-}$(1.53).

Groundwater in zone I contains a lower concentration of all chemical species compared to those in zones II to VI (Table 3). Thus, this is considered as a baseline to probe into extent of contaminants in the remaining zones. Significantly, concentrations (mg/L) of $\mathrm{Na}^{+}$(199) and $\mathrm{Cl}^{-}$(209) increase gradually from zone I to zone IV $\left(\mathrm{Na}^{+}: 481\right.$ and $\left.\mathrm{Cl}^{-}: 775\right)$ and suddenly in zones $\mathrm{V}$ and $\mathrm{VI}\left(\mathrm{Na}^{+}\right.$: 678-692 and $\mathrm{Cl}^{-}$: 1,082-1,288). Similarly, concentrations (mg/L) of $\mathrm{Mg}^{2+}$ (115-185) in zones V to VI and $\mathrm{SO}_{4}^{2-}(103-182)$ in zones IV to VI are higher than those in the remaining zones $\left(\mathrm{Mg}^{2+}\right.$ : 48-85 and $\mathrm{SO}_{4}^{2-}:$ 51-71). This indicates the influence of salt pans and aqua-cultural activities on groundwater quality, especially in zones $\mathrm{V}$ and VI. On the other hand, concentration $(\mathrm{mg} / \mathrm{L})$ of $\mathrm{NO}_{3}^{-}(59-84)$ in zones IV to $\mathrm{VI}$ is more than that in zones I to III (42-43). This reflects an anthropogenic pollution caused by indiscriminate dumping of domestic wastes onto ground, leakage of septic tanks and unlimited usage of agro-chemicals aspiring for higher crop yields. The higher concentration $(\mathrm{mg} / \mathrm{L})$ of $\mathrm{F}^{-}$in zones $\mathrm{V}$ and VI (1.27-1.53) compared to that in zones I to IV (0.771.00) is a consequence of $\mathrm{F}^{-}$-bearing minerals in the country rocks, clays, agro-chemicals and higher brackish groundwater (Subba Rao et al. 2014).

Hydrogeochemical facies

In the present study area (Chirala to Ongole), two hydrogeochemical facies (Table 4) viz. $\mathrm{Na}^{+}>\mathrm{Mg}^{2+}>$ $\mathrm{Ca}^{2+}: \mathrm{HCO}_{3}^{-}>\mathrm{Cl}^{-}>\mathrm{SO}_{4}^{2-}$ in first zone and $\mathrm{Na}^{+}>$ $\mathrm{Mg}^{2+}>\mathrm{Ca}^{2+}: \mathrm{Cl}^{-}>\mathrm{HCO}_{3}^{-}>\mathrm{SO}_{4}^{2-}$ in second to sixth zones are observed. The dominant of $\mathrm{Na}^{+}$among cations in both the facies is a consequence of a rock-weathering and/ 
Table 2 Classification of groundwater quality zones based on TDS range

\begin{tabular}{llll}
\hline Zone & TDS range $(\mathrm{mg} / \mathrm{L})$ & Sample numbers (Fig. 1) & Quality of groundwater \\
\hline I & $<1,000$ & $1-11$ & Fresh \\
II & $1,000-1,500$ & $12,13,15,16,39-42$ and $46-50$ & Very low brackish \\
III & $1,500-2,000$ & $14,17,18,32-35,37,38$ and $43-45$ & Low brackish \\
IV & $2,000-2,500$ & 19,25 and 36 & Moderate brackish \\
V & $2,500-3,000$ & $20,22-24,26,30$ and 31 & High brackish \\
VI & $>3,000$ & 21 and $27-29$ & Very high brackish \\
\hline
\end{tabular}

Table 3 Mean chemical composition of groundwater in different zones

\begin{tabular}{lllllllllllll}
\hline Zones & $\mathrm{pH}$ & $\mathrm{EC} \mu \mathrm{S} / \mathrm{cm}$ & $\begin{array}{l}\mathrm{TDS} \\
\mathrm{mg} / \mathrm{L}\end{array}$ & $\mathrm{Ca}^{2+}$ & $\mathrm{Mg}^{2+}$ & $\mathrm{Na}^{+}$ & $\mathrm{K}^{+}$ & $\mathrm{HCO}_{3}^{-}$ & $\mathrm{Cl}^{-}$ & $\mathrm{SO}_{4}^{2-}$ & $\mathrm{NO}_{3}^{-}$ & $\mathrm{F}^{-}$ \\
\hline I & 7.76 & $1,478.32$ & 960.91 & 40.45 & 48.18 & 199.36 & 12.18 & 416.67 & 209.09 & 51.36 & 43.36 & 0.77 \\
II & 7.64 & $2,092.31$ & $1,360.00$ & 46.54 & 66.92 & 301.38 & 21.85 & 449.00 & 451.92 & 61.77 & 41.54 & 0.87 \\
III & 7.80 & $2,656.41$ & $1,726.67$ & 50.83 & 70.42 & 414.67 & 24.17 & 419.33 & 661.67 & 70.67 & 41.92 & 0.90 \\
IV & 7.93 & $3,202.57$ & $2,081.67$ & 50.00 & 85.00 & 480.67 & 42.67 & 423.33 & 775.00 & 103.00 & 59.33 & 1.00 \\
V & 7.91 & $4,248.35$ & $2,761.43$ & 47.14 & 115.00 & 678.00 & 57.00 & 437.14 & $1,082.14$ & 181.71 & 79.71 & 1.27 \\
VI & 8.20 & $4,901.92$ & $3,186.25$ & 72.50 & 185.00 & 692.25 & 58.00 & 502.50 & $1,287.50$ & 156.25 & 84.00 & 1.53 \\
\hline
\end{tabular}

Table 4 Hydrogeochemical facies

\begin{tabular}{ll}
\hline Zone & Hydrogeochemical facies \\
\hline I & $\mathrm{Na}^{+}>\mathrm{Mg}^{2+}>\mathrm{Ca}^{2+}: \mathrm{HCO}_{3}^{-}>\mathrm{Cl}^{-}>\mathrm{SO}_{4}^{2-}$ \\
II & $\mathrm{Na}^{+}>\mathrm{Mg}^{2+}>\mathrm{Ca}^{2+}: \mathrm{Cl}^{-}>\mathrm{HCO}_{3}^{-}>\mathrm{SO}_{4}^{2-}$ \\
III & $\mathrm{Na}^{+}>\mathrm{Mg}^{2+}>\mathrm{Ca}^{2+}: \mathrm{Cl}^{-}>\mathrm{HCO}_{3}^{-}>\mathrm{SO}_{4}^{2-}$ \\
IV & $\mathrm{Na}^{+}>\mathrm{Mg}^{2+}>\mathrm{Ca}^{2+}: \mathrm{Cl}^{-}>\mathrm{HCO}_{3}^{-}>\mathrm{SO}_{4}^{2-}$ \\
V & $\mathrm{Na}^{+}>\mathrm{Mg}^{2+}>\mathrm{Ca}^{2+}: \mathrm{Cl}^{-}>\mathrm{HCO}_{3}^{-}>\mathrm{SO}_{4}^{2-}$ \\
VI & $\mathrm{Na}^{+}>\mathrm{Mg}^{2+}>\mathrm{Ca}^{2+}: \mathrm{Cl}^{-}>\mathrm{HCO}_{3}^{-}>\mathrm{SO}_{4}^{2-}$ \\
\hline
\end{tabular}

or dissolution of soil salts, which later remains in the soils by the influences of evaporation, anthropogenic and marine sources (Stallard and Edmond 1983; Subba Rao 2002; Subba Rao et al. 2014). Among anions, $\mathrm{HCO}_{3}^{-}$is dominant in first facies and $\mathrm{Cl}^{-}$in second facies. A higher $\mathrm{HCO}_{3}^{-}$classifies the area as a recharge zone, indicating an intense mineral weathering and favouring mineral dissolution (Stumm and Moran 1996). On the other hand, a predominance of $\mathrm{Cl}^{-}$ distinguishes it as a discharge zone and arises mainly by geogenic (clays), anthropogenic (domestic wastes, leakage of septic tanks and agro-chemicals) and marine (salt pans and aqua-cultural activities) sources. Thus, the difference in the facies clearly explains the distribution and genesis of principal groundwater types along the water flow-paths.

Genetic classification of groundwater chemistry

Quality of groundwater is classified into two major groups (Table 5), following the genetic classification of water chemistry (Chebotarev 1955). First group is related to
Table 5 Genetic classification of groundwater chemistry (after Chebotarev 1955)

\begin{tabular}{llll}
\hline Major group & Division & Genetic type & Zone \\
\hline $\mathrm{HCO}_{3}^{-}$ & I & $\mathrm{HCO}_{3}^{-}$ & I \\
& III & $\mathrm{Cl}^{-}-\mathrm{HCO}_{3}^{-}$ & II \\
$\mathrm{Cl}^{-}$ & III & $\mathrm{Cl}^{-}-\mathrm{HCO}_{3}^{-}$ & III to VI \\
\hline
\end{tabular}

genetic type of major division of $\mathrm{HCO}_{3}^{-}$in zones I and II, which comprises of $\mathrm{HCO}_{3}^{-}$and $\mathrm{Cl}^{-}-\mathrm{HCO}_{3}^{-}$. This reflects an influence of intensive water flushing due to occurrence of good drainage conditions, resulting from a relative occurrence of more sand in aquifer material. Second group belongs to genetic type of $\mathrm{Cl}^{-}-\mathrm{HCO}_{3}^{-}$under a major division of $\mathrm{Cl}^{-}$in zones III to VI. This indicates inadequate water flushing due to poor drainage conditions arising from geogenic, anthropogenic and marine sources. Thus, this genetic classification obviously distinguishes the sources of dissolved ions in groundwater.

Mechanisms of groundwater chemistry

\section{Langelier-Ludwig diagram}

Groundwater chemistry is a tool to probe into mechanisms of chemical interaction of water with ions from different sources. Percentages of $\mathrm{Ca}^{2+}+\mathrm{Mg}^{2+} \quad(28-40 \%)$, $\mathrm{Na}^{+}+\mathrm{K}^{+}(60-72 \%), \mathrm{HCO}_{3}^{-}(18-50 \%)$ and $\mathrm{Cl}^{-}+\mathrm{SO}_{4}^{2-}$ (51-82 \%; Table 6) are superimposed on Langelier-Ludwig (1942) diagram (Fig. 3). No groundwater point of any zone 
is observed from a meteoric-derived groundwater domain $\left(\mathrm{Ca}^{2+}+\mathrm{Mg}^{2+}+\mathrm{HCO}_{3}^{-}\right)$. The composition of ions in zone I has a higher percentages of $\mathrm{Na}^{+}+\mathrm{K}^{+}$and $\mathrm{HCO}_{3}^{-}$due to mineral dissolution and absorption of large amounts of $\mathrm{CO}_{2}$ during infiltration of recharge water. The chemical composition in zones II to VI has a higher percentage of $\mathrm{Na}^{+}+\mathrm{K}^{+}$and $\mathrm{Cl}^{-}+\mathrm{SO}_{4}^{2-}$. It is a cumulative effect of sluggish drainage conditions, poor sanitary facilities, uncontrolled usage of agro-chemicals, salt pans and aquacultural activities on groundwater system.

\section{Gibbs diagram}

Ratios of cations $\left(\mathrm{Na}^{+}+\mathrm{K}^{+}: \mathrm{Na}^{+}+\mathrm{K}^{+}+\mathrm{Ca}^{2+}=\right.$ 0.81-0.93) and anions $\left(\mathrm{Cl}^{-}: \mathrm{Cl}^{-}+\mathrm{HCO}_{3}^{-}=0.46-0.82\right)$ in the study area (Table 7) are plotted against TDS in the popular Gibbs diagram (Fig. 4). It explains the influences of atmospheric precipitation (rainwater), rock-water

Table 6 Percentages of chemical species in groundwater samples

\begin{tabular}{lllll}
\hline Zone & $\mathrm{Ca}^{2+}+\mathrm{Mg}^{2+}$ & $\mathrm{Na}^{+}+\mathrm{K}^{+}$ & $\mathrm{HCO}_{3}^{-}$ & $\mathrm{Cl}^{-}+\mathrm{SO}_{4}^{2-}$ \\
\hline I & 39.98 & 60.02 & 49.50 & 50.50 \\
II & 36.41 & 63.59 & 34.40 & 65.60 \\
III & 30.87 & 69.13 & 25.45 & 74.55 \\
IV & 30.13 & 69.87 & 22.42 & 77.58 \\
V & 27.79 & 72.21 & 19.01 & 80.99 \\
VI & 37.52 & 62.48 & 18.48 & 81.52 \\
\hline
\end{tabular}

interaction (lithology) and evaporation (climate) on groundwater.

Zone I falls in a rock-domain, while zones II to VI are observed from a domain of evaporation. The rock-water interaction arises due to dissolved ions in zone I. The change of chemical composition from domain of rock towards evaporation domain causes an increase of $\mathrm{Na}^{+}$ and $\mathrm{Cl}^{-}$, and consequently a higher TDS. This is a result of influences of geogenic, anthropogenic and marine sources on groundwater body. Thus, the chemical composition of groundwater samples (zones II to VI) increases towards domain of evaporation from rock domain (zone I).

Table 7 Geochemical signatures

\begin{tabular}{|c|c|c|c|c|c|}
\hline \multirow[t]{2}{*}{ Zone } & \multicolumn{5}{|c|}{ Geochemical signatures } \\
\hline & $\begin{array}{l}\mathrm{Na}^{+}: \\
\mathrm{Na}^{+}+\mathrm{Ca}^{2+}\end{array}$ & $\begin{array}{l}\mathrm{Cl}^{-}: \\
\mathrm{Cl}^{-}+\mathrm{HCO}_{3}^{-}\end{array}$ & $\mathrm{HCO}_{3}^{-}: \mathrm{Cl}^{-}$ & $\mathrm{Na}^{+}: \mathrm{Cl}^{-}$ & $\mathrm{SAR}^{*}$ \\
\hline I & 0.81 & 0.46 & 1.16 & 1.47 & 5.02 \\
\hline II & 0.85 & 0.63 & 0.58 & 1.03 & 6.63 \\
\hline III & 0.88 & 0.73 & 0.37 & 0.97 & 8.84 \\
\hline IV & 0.89 & 0.76 & 0.32 & 0.96 & 9.60 \\
\hline V & 0.93 & 0.81 & 0.23 & 0.97 & 12.14 \\
\hline VI & 0.89 & 0.82 & 0.23 & 0.83 & 9.81 \\
\hline
\end{tabular}

Fig. 3 Gibbs plot for mechanisms controlling groundwater chemistry
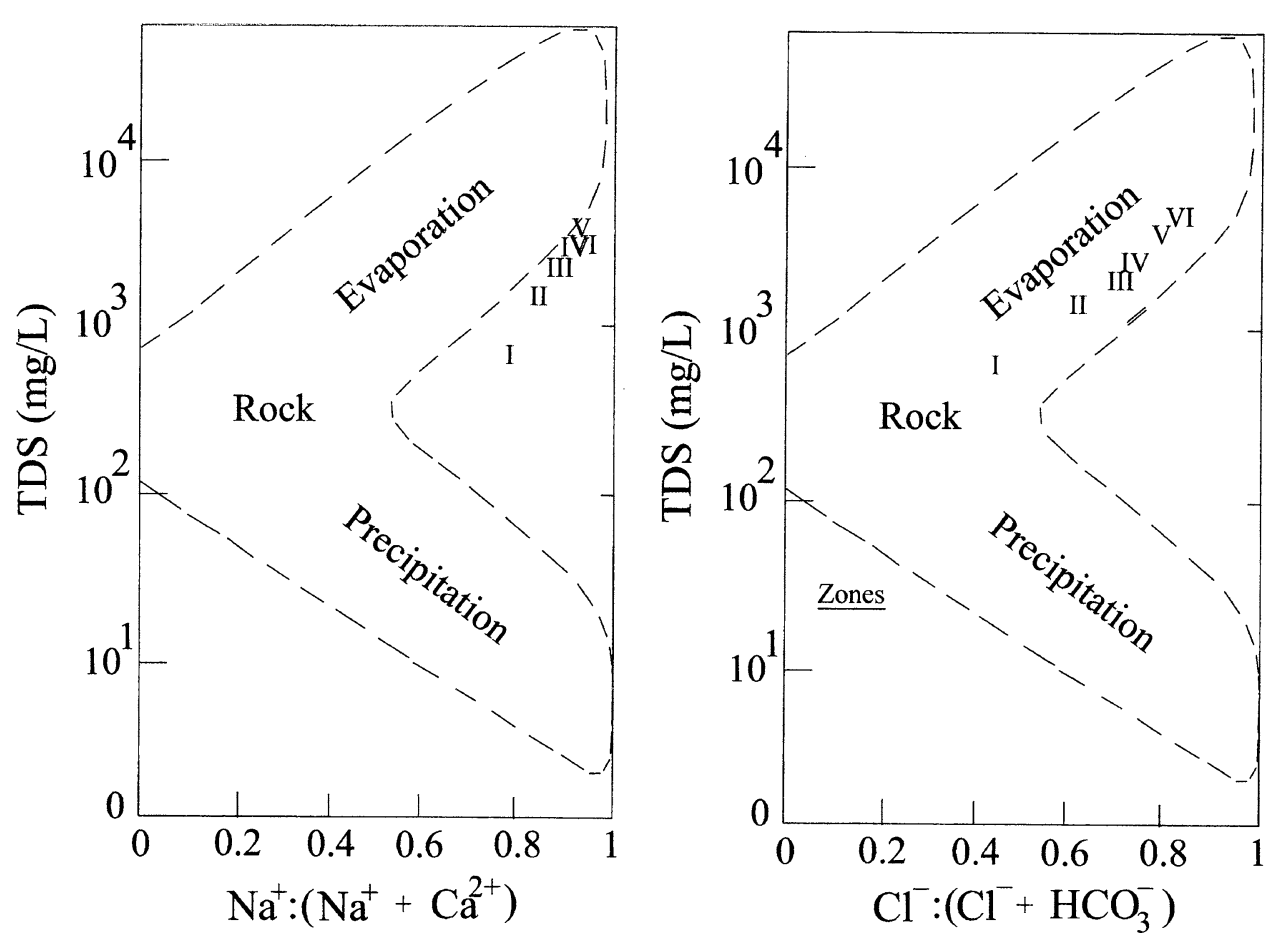


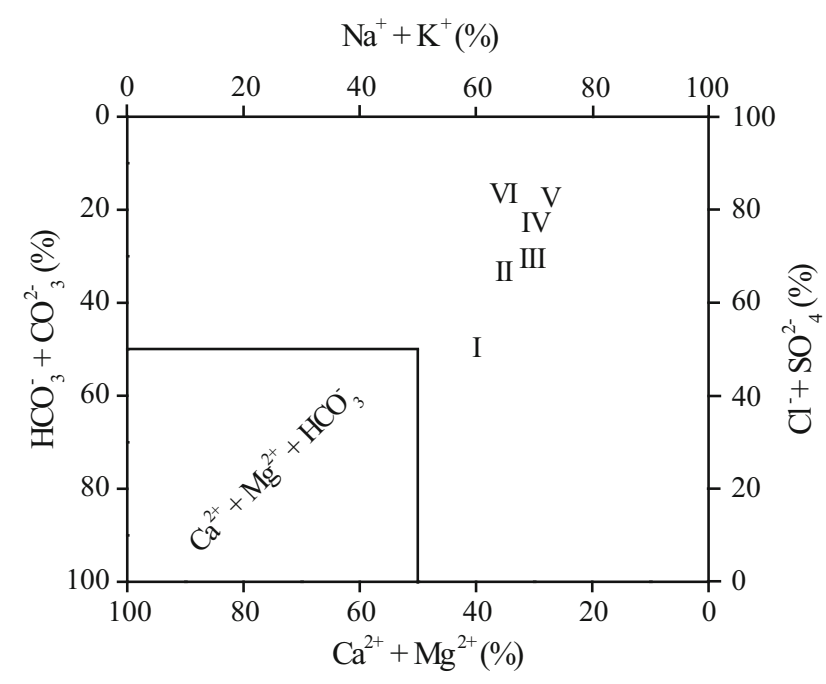

Fig. 4 Langelier and Ludwig diagram for mineral characteristics of groundwater

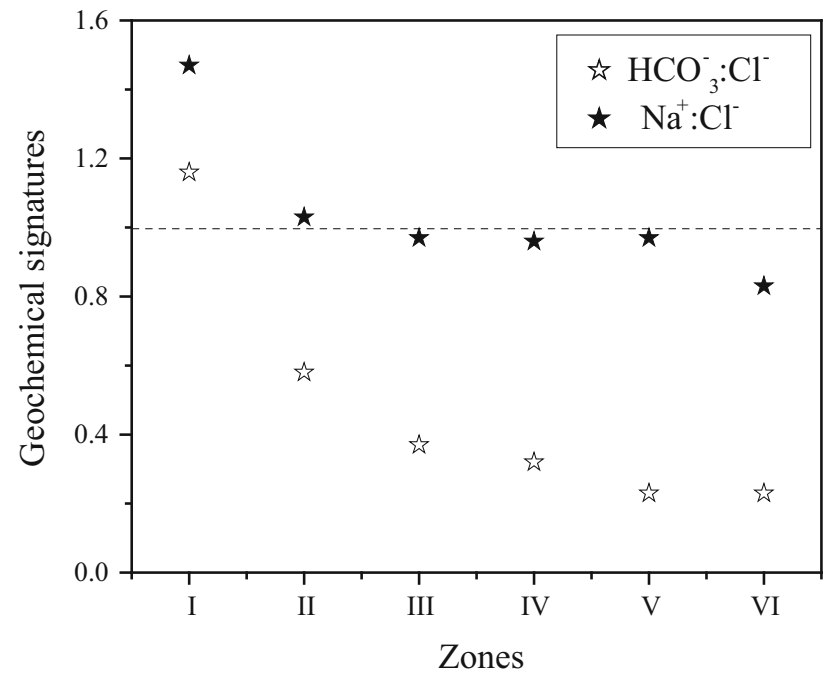

Fig. 5 Geochemical signatures in the present study zones

Geochemical signatures

Geochemical signatures $\left(\mathrm{HCO}_{3}^{-}: \mathrm{Cl}^{-}\right.$and $\left.\mathrm{Na}^{+}: \mathrm{Cl}^{-}\right)$speak of the quality of water from different sources (Hem 1991). The concentration of $\mathrm{HCO}_{3}^{-}$is high in groundwater and $\mathrm{Cl}^{-}$ in seawater. The ratio of $\mathrm{HCO}_{3}^{-}: \mathrm{Cl}^{-}$is 1.16 in zone I (Table 7; Fig. 5), resulting from an interaction of water with aquifer material. If the groundwater is contaminated by marine origin, then it masks the contribution of anthropogenic origin. The range of ratio of $\mathrm{Na}^{+}: \mathrm{Cl}^{-}$is $0.83-0.97$ in zones III to VI, indicating marine source. Further, clay content increases from Chirala to Ongole and thus it is one of the factors for increase of $\mathrm{Na}^{+}$and $\mathrm{Cl}^{-}$concentrations in groundwater. Therefore, groundwater contamination in zones III to VI is of anthropogenic and marine origin.
Criteria of groundwater quality

\section{Potability}

The hydrogeochemical factors of groundwater samples of six zones of the study area (Chirala to Ongole along the coast) are compared with stipulated limits of Davis and Dewiest (1966), Holden (1970) and BIS (2003) for potable groundwater.

The desirable range of $\mathrm{pH}$ for potable water stipulated is 6.5-8.5 and the values for the groundwater samples in the present study in all zones (7.8-9.2) are within these limits (Table 8). The concentration $(\mathrm{mg} / \mathrm{L})$ of $\mathrm{Ca}^{2+}(40-73)$ is below the recommended value of 75 in all zones. The values (mg/L) of TDS (961-3,186), $\mathrm{Mg}^{2+}(48-185)$ and $\mathrm{K}^{+}(12-58)$ in all zones, while the concentration of $\mathrm{Na}^{+}$ (301-692 $\mathrm{mg} / \mathrm{L})$ in zones II to VI in the study area exceed two to six fold the limits of the prescribed values of 500, 30, 200 and 10, respectively. Further, the concentration $(\mathrm{mg} / \mathrm{L})$ of $\mathrm{Cl}^{-}$is in large excess $(452-1,288)$ in zones II to VI, while $\mathrm{HCO}_{3}^{-}$(417-503) in all zones, $\mathrm{SO}_{4}^{2-}(156-182)$ in zones $\mathrm{V}$ and $\mathrm{VI}, \mathrm{NO}_{3}^{-}(59-84)$ in zones III to $\mathrm{VI}$ and $\mathrm{F}^{-}$ (1.27-1.53) in zones $\mathrm{V}$ and VI are more than allowable anion limits of 250, 300, 150, 45 and 1.20, respectively, for drinking. The higher concentrations of these chemical species much over prescribed limits have cumulative effects on human health.

\section{Irrigation}

A low quality groundwater is unsuitable even for irrigation purpose. Salinity measured as EC and sodium are two factors of the United States of Salinity Laboratory (USSL) diagram (Richards 1954; Fig. 6). The excess salinity, also called salinity hazard, causes crop loss by reducing the osmotic activity of plants. Sodium is vital for plant growth. But, very high concentrations of it, termed as sodium hazard, impair soil permeability resulting in deflocculation with a consequence of inadequate air and water circulation. Added to it, the present study has dry climate, worsening the soil conditions, which leads to reduced plant growth.

Values of EC and SAR are in the ranges of 1,478-4,902 (Table 3) and 5.02-12.14, respectively (Table 6). The groundwater of zone I falling in a division of C3S1 (high salinity and low sodium hazard) is useful for irrigation on almost all soil types, while that of zone II observed from a division of C3S2 (high salinity and medium sodium hazard) is safe on coarse textured or organic soils only (Fig. 6, Table 9). But, the groundwater of zones III to VI falling in a division of C4S2 (very high salinity and medium sodium hazard) is not suitable for irrigation. Thus, it requires 
Table 8 Groundwater quality for drinking (after Davis and Dewiest, 1966; Holden, 1970; BIS, 2003)

\begin{tabular}{llllll}
\hline Factors* & Unit & Desirable limit & Range & O-D ratio** & Health implications \\
\hline $\mathrm{pH}$ & & $6.5-8.5$ & $7.76-8.20$ & Within limit & - \\
$\mathrm{TDS}$ & $\mathrm{mg} / \mathrm{L}$ & 500 & $960.91-3,186.25$ & $1.92-6.37$ & Gastrointestinal irritation \\
$\mathrm{Ca}^{2+}$ & $\mathrm{mg} / \mathrm{L}$ & 75 & $40.45-72.50$ & Below limit & - \\
$\mathrm{Mg}^{2+}$ & $\mathrm{mg} / \mathrm{L}$ & 30 & $48.18-185.00$ & $1.60-6.17$ & Laxative agent \\
$\mathrm{Na}^{+}$ & $\mathrm{mg} / \mathrm{L}$ & 200 & $199.36-692.25$ & $1.51-3.46$ & Hypertension \\
$\mathrm{K}^{+}$ & $\mathrm{mg} / \mathrm{L}$ & 10 & $12.18-58.00$ & $1.20-5.80$ & Maintains fluids in balance stage \\
$\mathrm{HCO}_{3}^{-}$ & $\mathrm{mg} / \mathrm{L}$ & 300 & $416.67-502.50$ & $1.39-1.68$ & Helps for digestion of food \\
$\mathrm{Cl}^{-}$ & $\mathrm{mg} / \mathrm{L}$ & 250 & $209.09-1,287.50$ & $1.81-5.15$ & Salty taste \\
$\mathrm{SO}_{4}^{2-}$ & $\mathrm{mg} / \mathrm{L}$ & 150 & $51.36-156.25$ & $1.04-1.21$ & Sour taste, and skin and repertory problems \\
$\mathrm{NO}_{3}^{-}$ & $\mathrm{mg} / \mathrm{L}$ & 45 & $43.36-84.00$ & $1.31-1.87$ & Methaemoglobinemia \\
$\mathrm{F}^{-}$ & $\mathrm{mg} / \mathrm{L}$ & 1.20 & $0.77-1.53$ & $1.06-1.28$ & Fluorosis \\
\hline
\end{tabular}

* Factors influencing quality of groundwater ** Observedvalue

Desriable limit

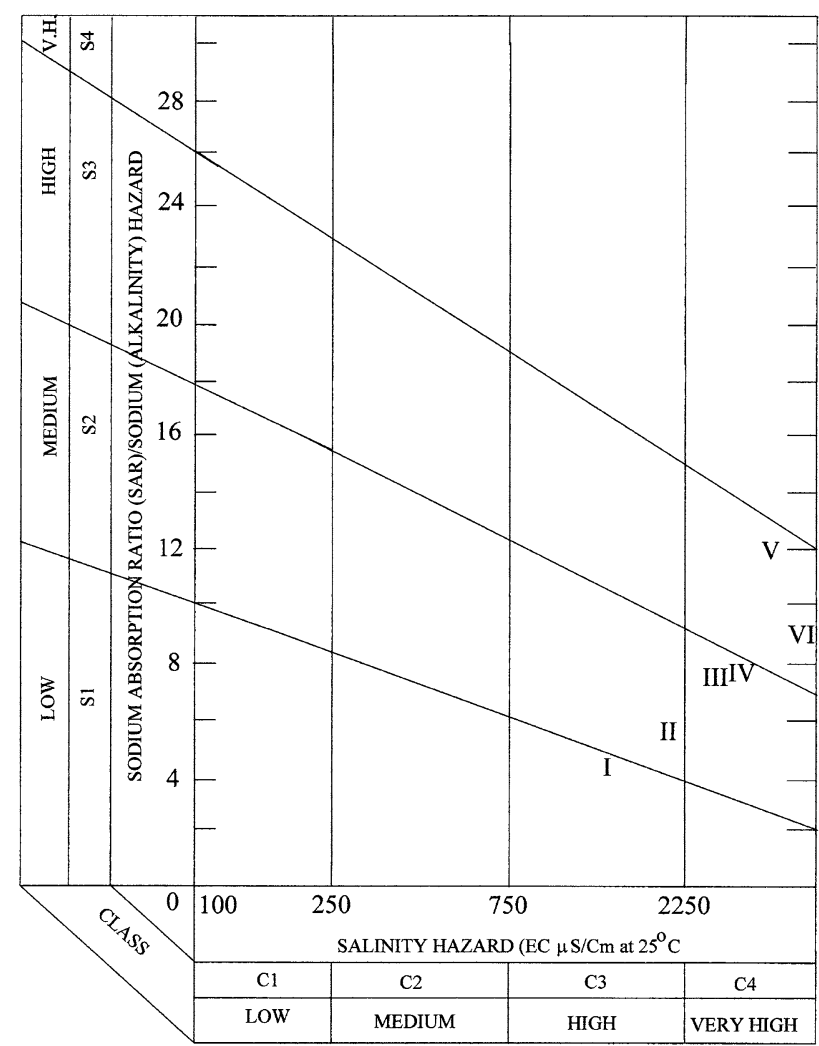

Fig. 6 Richards diagram for classification of groundwater quality for irrigation

remedial measures (desalination and dealkalination) to improve soil conditions.

\section{Industry}

Incrustation and corrosion are functional and economic devastating phenomena in industrial sector, primarily due to poor quality of water. It is further aggravated by humidity and ions in the atmosphere. In incrustation, $\mathrm{CaCO}_{3}$ deposition occurs on metal surfaces and is prevalent, if water contains $\mathrm{HCO}_{3}^{-}$more than $400 \mathrm{mg} / \mathrm{L}$ and/or $\mathrm{SO}_{4}^{2-}$ greater than $100 \mathrm{mg} / \mathrm{L}$ (Table 10). Corrosion results in poly-nuclear metal oxides and hydroxides, and acidic $\mathrm{pH}$ $(<7)$, TDS $>1,000 \mathrm{mg} / \mathrm{L}$ and/or $\mathrm{Cl}^{-}>500 \mathrm{mg} / \mathrm{L}$ promote these chemical interactions.

Incrustation is possible, if the groundwater in the present study area is used in industry. This is because $\mathrm{HCO}_{3}^{-} \quad(417-503 \mathrm{mg} / \mathrm{L})$ exceeds the upper limit of $400 \mathrm{mg} / \mathrm{L}$ (Table 9). The effect is augmented in zones III to VI, as $\mathrm{SO}_{4}^{2-}$ also is above the permissible concentration of $100 \mathrm{mg} / \mathrm{L}$. From the corrosion perspective, the higher amounts of TDS (961-3,186 mg/L) in second to sixth zones and $\mathrm{Cl}^{-}(662-1,288 \mathrm{mg} / \mathrm{L})$ in third to sixth zones exceed the prescribed limits of $1,000 \mathrm{mg} / \mathrm{L}$ and $500 \mathrm{mg} / \mathrm{L}$, respectively. It renders the water not useful for industry. Thus, the groundwater in the present study area as a whole is not suitable even for industrial purposes.

\section{Remedial measures for pollution of groundwater}

In spite of natural eco-balance, the rate and intensity of contamination of groundwater resources too crossed the safe limits. It warrants again man-made intervention on farm scientific approaches for remedial measures both in local and global scenarios.

- Improved sanitary facilities to control inflow of domestic and industrial wastes $\left(\mathrm{Na}^{+}, \mathrm{Cl}^{-}, \mathrm{NO}_{3}^{-}\right.$and $\mathrm{Mg}^{2+}$ ions) into groundwater system.

- Application of agro-chemicals based on soil characteristics, but not aspiring for higher crop yields. 
Table 9 Quality of groundwater for irrigation (after Richards 1954)

\begin{tabular}{llllll}
\hline Zone & Division & Salinity hazard & Sodium hazard & Suitability for irrigation & Soil management measures \\
\hline I & C3S1 & High & Low & Almost all soils & - \\
II & C3S2 & High & Medium & Coarse or organic soils & - \\
III & C4S2 & Very high & Medium & - & Good drainage, leaching and addition of organic matter \\
IV & C4S2 & Very high & Medium & - & Good drainage, leaching and addition of organic matter \\
V & C4S3 & Very high & High & - & Desalination and dealkalination \\
VI & C4S3 & Very high & High & - & Desalination and dealkalination \\
\hline
\end{tabular}

Table 10 Quality criteria for groundwater use for industry (after Johnson, 1983)

\begin{tabular}{lcll}
\hline Factor $*$ & Standard limit & \multicolumn{2}{l}{ Effect zones with respect to } \\
\cline { 3 - 4 } & & Incrustation & Corrosion \\
\hline $\mathrm{pH}$ (units) & $<7$ & - & - \\
$\mathrm{TDS}(\mathrm{mg} / \mathrm{L})$ & $>1,000$ & - & II-VI \\
$\mathrm{HCO}_{3}^{-}(\mathrm{mg} / \mathrm{L})$ & $>400$ & $\mathrm{I}-\mathrm{VI}$ & - \\
$\mathrm{Cl}^{-}(\mathrm{mg} / \mathrm{L})$ & $>500$ & - & III-VI \\
$\mathrm{SO}_{4}^{2-}(\mathrm{mg} / \mathrm{L})$ & $>100$ & III-VI & - \\
\hline
\end{tabular}

* Factors influencing quality of groundwater

- Implementation of environmental strictures to minimize $\left(\mathrm{Na}^{+}\right.$and $\left.\mathrm{Cl}^{-}\right)$pollution in the areas of saltmaking and aqua-cultural activities.

- Increase of number of rainwater harvesting structures is crucial to reduce the intensity of brackishness, including $\mathrm{F}^{-}$content in groundwater.

- Intensive training of social workers on implications of ill-effects of pollution on human health, irrigation and industry is important.

- Timely policy-making and execution by civic authorities is a key factor to mitigate the hazards of pollution case by case basis.

\section{Conclusions}

Groundwater samples analyzed in the study area (Chirala to Ongole) are alkaline. TDS classification shows that first zone is of fresh water type (TDS $<1,000 \mathrm{mg} / \mathrm{L}$ with $\mathrm{Na}^{+}>\mathrm{Mg}^{2+}>\mathrm{Ca}^{2+}: \mathrm{HCO}_{3}^{-}>\mathrm{Cl}^{-}>\mathrm{SO}_{4}^{2-}$ facies), while second to sixth zones are brackish water category (TDS > $1,000 \mathrm{mg} / \mathrm{L}$ with $\mathrm{Na}^{+}>\mathrm{Mg}^{2+}>\mathrm{Ca}^{2+}: \mathrm{Cl}^{-}>\mathrm{HCO}_{3}^{-}>\mathrm{SO}_{4}^{2-}$ facies). Division of the study area on genetic classification basis showing first and second zones has good drainage conditions $\left(\mathrm{HCO}_{3}^{-}\right.$type $)$and the rest of zones with poor drainage conditions $\left(\mathrm{Cl}^{-}\right.$type). From the Gibbs and Langelier-Ludwig diagrams, and geochemical signatures, it is inferred that rock-water interaction is prominent in first zone, while sluggish drainage conditions in second to sixth zones due to influences of geogenic, anthropogenic and marine sources. The water in all zones, except first one, is unsuitable for drinking, irrigation and industrial purposes. The technical measures to prevent further pollution, planning strategies and knowledge sharing are briefly described.

Acknowledgments The authors acknowledge the financial assistance supported by the Department of Science and Technology, Government of India, New Delhi under a major research project (DST/WAR-W/WSI/08/2010). Sincere thanks Prof. R. Sambasiva Rao, Department of Chemistry, Andhra University for his critical and constructive suggestions in improving the revised manuscript. The authors are also thankful to anonymous reviewers and editor of the journal for their valuable suggestions in bringing the manuscript in the present form.

Open Access This article is distributed under the terms of the Creative Commons Attribution License which permits any use, distribution, and reproduction in any medium, provided the original author(s) and the source are credited.

\section{References}

APHA (1999) Standard methods for the examination of water and wastewater. American Public Health Association, Washington, DC

Back W (1966) Hydrochemical facies and groundwater flow pattern in northern part of Atlantic Coastal Plain. U.S. Geological Survey Professional Paper 498A, p 42

Bhavana NU, Devi NM (2011) Groundwater quality assessment for Guhagar coastal area, Maharashtra, India. J Environ Res Dev 5:880-891

BIS (2003) Indian standard specifications for drinking water. IS:10500, Bureau of Indian Standards, New Delhi

Central Ground Water Board (2002) Basic data reports of exploratory wells drilled in Prakasam District. Central Ground Water Board, Southern Region, Hyderabad

Chebotarev II (1955) Metamorphism of natural waters in the crust of weathering. Geochimica Cosmochim Acta 8: 22-48, 137-170 and $198-212$

Chidambaram S, Senthil Kumar G, Prasanna MV, John Peter A, Ramanathan AL, Srinivasamoorthy K (2009) A study on the hydrogeology and hydrogeochemistry of groundwater from different depths in a coastal aquifer: Annamalai Nagar, Tamilnadu. Environ Geol 57:59-73 
Davis SN, Dewiest RJM (1966) Hydrogeology. John Wiley and Sons Inc, New York, p 463

Domenico PA, Schwartz FW (1990) Physical and chemical hydrogeology. Wiley, New York, p 824

Fetter CW (1990) Applied hydrogeology. CBS Publishers \& Distributors, New Delhi, p 592

Gibbs RJ (1970) Mechanism controlling world's water chemistry. Science 170:1088-1090

Hem JD (1991) Study and interpretation of the chemical characteristics of natural water. United States Geological Survey Professional Paper 2254, Scientific Pub. Jodhpur

Holden WS (1970) Water treatment and examination. J \& Churchill Publishers, London, p 513

Johnson EE (1983) Groundwater and wells. Ist Indian edition, Jain Brothers, Udaipur, p 440

Kumar Bhishm, Rao MS, Gupta AK, Purushothaman P (2011) Groundwater management in a coastal aquifer in Krishna River Delta, South India using isotopic approach. Curr Sci 100:1032-1043

Langelier WF, Ludwig HF (1942) Graphic method for indicating the mineral character of natural water. J Am Water Works Assoc 34:335-352

Manjusree TM, Joseph Sabu, Thomas Jobin (2009) Hydrogeochemistry and groundwater quality in the coastal sandy clay aquifers of Alappuzha district, Kerala. J Geol Soc India 74:459-468

Mondal NC, Singh VP, Singh S, Singh VS (2011) Hydrochemical characteristic of coastal aquifer from Tuticorin, Tamil Nadu, India. Environ Monit Assess 175:531-550

Reddy AGS (2013) Evaluation of hydrogeochemical characteristics of phreatic alluvial aquifers in southeastern coastal belt of Prakasam district, South India. Environ Earth Sci 68:471-485

Richards LA (1954) Diagnosis and Improvement of Saline and Alkalis Soils. US Department of Agriculture Handbook 60, p 160

Sajil Kumar PJ, Elango L, James EJ (2014) Assessment of hydrochemistry and groundwater quality in the coastal area of South Chennai, India. Arab J Geosci 7:2641-2653

Sarath Prasanth SV, Magesh NS, Jitheshlal KV, Chandrasekar N, Gangadhar K (2012) Evaluation of groundwater quality and its suitability for drinking and agricultural use in the coastal stretch of Alappuzha District, Kerala, India. Appl Water Sci 2:165-175

Seaber PR (1962) Cation hydrochemical facies of ground- water in the Englishtown Formation, New Jersey. US Geol Surv Prof Paper 450:124-126

Selvam S, Manimaran G, Sivasubramanian P (2013) Hydrochemical characteristics and GIS based assessment of groundwater quality in the coastal aquifers of Tuticorin Corporation, Tamilnadu, India. App Water Sci 3:145-159

Senthilkumar G, Ramanathan AL, Nainwal HC, Chidambaram S (2008) Evaluation of the hydrogeochemistry of groundwater using factor analysis in the Cuddalore coastal region, Tamilnadu, India. Indian J Mar Sci 37:181-185

Srinivasamoorthy M, Vasanthavigar S, Chidambaram S, Anandan P, Sharma VS (2011) Characterization of groundwater chemistry in an eastern coastal area of Cuddalore district, Tamilnadu. J Geol Soc India 78:549-558

Stallard RF, Edmond JM (1983) Geochemistry of the Amazon River-the influence of the geology and weath- ering environment on the dissolved load. J Geophys Res 88:9671-9688

Stumm W, Moran JJ (1996) Aquatic chemistry. Wiley-Interscience, New York

Subba Rao N (2002) Geochemistry of Groundwater in Parts of Guntur District, Andhra Pradesh, India. Environ Geol 41:552-562

Subba Rao N, Saroja Nirmal I, Suryanarayan K (2005) Groundwater quality in a coastal area-a case study from Andhra Pradesh, India. Environ Geol 48:534-550

Subba Rao N, Vidyasagar G, Surya Rao P, Bhanumurthy P (2014) Assessment of hydrogeochemical processes in a coastal region: application of multivariate statistical model. J Geol Soc India 84:494-500

Surya Rao P, Subba Rao N (2014) Quality of groundwater in a coastal region of Andhra Pradesh, South India. J App Geochem $16: 81-90$

Venkataramanan S, Ramkumar T, Vasudevan S, Ramesh G, Anitha Mary G, Viajayakumar V (2014) Assessment of hydrochemistry of groundwater in Muthupet coastal region, Tamilnadu, India. Int J App Environ Sci 4:165-172 